\title{
Bingöl'de yetiştirilen sığır sürülerinde Bovine Viral Diyare Virüs enfeksiyonunun varlığının ve yaygınlığının belirlenmesi
}

\author{
Metin Gürçay' (), Hakan Keçeci² (), Merve Öztürk3 ${ }^{3}$ (]) \\ $7^{*}$ Bingöl Üniversitesi Veteriner Fakültesi, Viroloji Anabilimdalı ,Düzağaç, Bingöl, Türkiye \\ 2,3 Bingöl Üniversitesi Veteriner Fakültesi, lç̧ hastalıkları Anabilimdalı, Düzağaç, Bingöl,Türkiye
}

Geliş Tarihi / Received: 13.12.2019, Kabul tarihi / Accepted: 05.05.2020

\begin{abstract}
Özet: Bovine Viral Diarrhoea Virus (BVDV) enfeksiyonu, sığır yetiştiriciliğinde önemli bir yetiştirme hastalığıdır. Persiste infekte $(\mathrm{PI})$ hayvanlar, hayvan sürüleri içinde ve sürüler arasında ana virüs taşıyıcıSı ve temel virüs bulaştırıcısıdır. Bu nedenle, sığır sürülerinde PI hayvanların varlığı belirlenmeli ve sürülerden uzaklaştırılmalıdır. Bu çalışmada, Bingöl ilinden farklı periyotlarda farklı amaçlar için Bingöl Üniversitesi Veteriner Fakültesi kliniklerine getirilen toplam 105 sığırdan kan örnekleri alındı. Bu kan örneklerinde BVDV antijeni ve antikorlarının varlığı, enzim immünolojik test (ELISA) ile test edildi. Örneklenen 105 numunenin 12'sinde (\% 11,42) BVDV antijeni ve 40'nda da (\% 38,09) BVDV antikorların varlığı tespit edildi. PI hayvanlar, BVDV antikoru taşımayan sadece antijen tespit edilenler olarak tanımlandı. Bingöl ilinde yetiştirilen sığır sürülerinde persiste BVDV varlığı, \% 2,85 oranında belirlendi. Rasyonel sığır yetiştiriciliği açısından BVDV enfeksiyonunun kontrol edilmesinin gerekliliği bu çalışma ile bir kez daha vurgulamıştır. Enfeksiyonun eradikasyonu, gelişmiş sürü sağlığına ek avantajlar sunar. Bununla birlikte sürülerin sıkı biyogüvenlik tedbirleriyle taranması da uygun bir sığır popülasyonu oluşturur.
\end{abstract}

Anahtar kelimeler: Antijen, Antikor,Bingöl, Sığır, Sığır İshal Virüsü

\section{Determination of presence and prevalence of Bovine Viral Diarrhea Virus infection in cattle herds in Bingol province}

\begin{abstract}
Bovine Viral Diarrhoea virus (PBVDV) infectionis an important cultivate disease in cattle breeding. Persistent infected (PI) animals are the main virüs carrier with in and between herds at virüs transmission. Therefore, the presence of persistent infected $(\mathrm{PI})$ animals should be determined and removed from the cattle herds. In this study, it was aimed to determine the presence and prevalence of BVDV infection in cattle herds in Bingöl. A total of 105 blood samples collected from cattle herds in Bingol were obtained by sampling from animals brought to Bingöl University Veterinary Faculty Clinics for different purposes. The presence of BVDV antigen and antibodies in these blood samples was investigated by Enzyme-Linked Immunosorbent Assay (ELISA) test. The presence of BVDV antigens in $12(11.42 \%)$ and antibodies in 40 (38.09\%) were detected of the samples. On the otherhand in the tree cattle BVDV antibodywas not detected but only the antigen was detected. Although the presence of antigens could be detected in the three cattle, antibody could not be detected, which was evaluated as the animals were persistent. In this study, the presence of persistant BVDV infection in cattle herds the region was demonstrated $2.85 \%$. It has emphasized the need to control of the BVDV infections in the region for rational cattle breeding. Eradication offers the supplementary advantage of developed herdhealth; however, it also compose favorable cattle population that needs to be screened by strict biosecurity.
\end{abstract}

Key words: Antibody, Antigene, Bingol, Bovine Viral Diarrehoe Virüs, Cattle

\section{Giriş}

Bovine Viral Diyare Virüs (BVDV) enfeksiyonu, sığırların Türkiye dahil dünya çapında ana patojenlerinden biridir. Virüs, Flaviviridae familyasındaki Pestivirus cinsinde yer alır. Pestiviruslar dört tür içerir. Bunlar; Bovine Viral Diyare Virüs, Border Disease virüs (BDV), Classical Swine Fever virüs (CSFV) ve ayrıca zürafadan izole edilen yeni bir türdür (Erol ve ark.2014). BVDV, BVDV1, ve BVDV2 diye iki geno- tipe ayrilır. BVDV2'nin dört alt genotipi, BVDV1'in minimum 21 alt genotipi tanımlanmıştır (Alpay ve ark. 2019; Oğuzoğlu ve ark. 2019). BVDV'nin yaklaşık 12.5 kilobazlık tek sarmallı, pozitif polariteli bir RNA genomu vardır. Virüs sitopatojenik (CP) olan ve sitopatojenik olmayan (NCP) iki biyotipten oluşur. Genellikle sahada en fazla izole edilmiş olanı NCP'dir. Hücre ölümüne neden olmadan monoleyer hücre kültüründe çoğalır. Persistent ve ömür boyu 
bir enfeksiyonu oluşturabilmek için gebe sığırlarda plasentayı geçebilir (Fray ve ark. 2000). PI buzağılar, uterusta embriyonik gelişimin 45.gününden 125. gününe kadar gebe sığırlarda virüsün plasentayı geçmesi ve immun yetersiz fötüsün enfeksiyonu sonucu oluşur (Walz ve ark. 2010). Virüsün CP biyotipleri, NCP virüsünün mutasyonu ile ortaya çıkabilir (Donis 1995; Houe 1999).

BVDV, sığırlarda ishal, kısırlık, yavru atma, solunum yolu hastalıkları, düşük büyüme performansı, diğer enfeksiyonlara yakalanma sıklığının artmaSI, gebe ineklerde fetüsün persiste enfeksiyonu ve ölümüne neden olabilir. BVDV'nin bulaşması çeşitli şekillerde olur. Çoğunlukla duyarlı hayvanların akut enfeksiyon geçiren veya persiste enfekte hayvanlarla direkt temas sonucu gerçekleşmektedir. Ayrıca enfekte bireylere ait gözyaşı-burun akıntıları, tükrük, semen, dışkı, idrar, ter ve süt gibi tüm salgılarla indirekt olarak temas ile de bulaşır. Ek olarak kontamine aşılar, embriyo transferi, aşılama ve enjeksiyon gibi iatrojenik yollarla da bulaşma gerçekleşebilir. Persistent enfekte (PI) hayvanlar birincil enfeksiyon kaynağıdır, PI hayvanla doğrudan temas virüsün iletilmesinde önemlidir ve bu hayvanlar hayatları boyunca çok miktarda virüs saçarlar (Richter ve ark. 2017; Alpay ve ark. 2019). Bununla birlikte, PI hayvanlar BVDV'ye spesifik antikorlar geliştirmez. Bu hayvanlar sadece yaşamları boyunca virüsü saçmakla kalmaz, aynı zamanda persistent bir hayvan doğumuna da yol açar. PI hayvanları sürüden ayrılmadığında, klinik semptomlardan kaynaklanan ekonomik kayıplar yeterince kontrol edilemez (Richter ve ark. 2017; Alpay ve ark. 2019). İnek, gebeliğin ilk üç ayında sitopatojenik olmayan BVDV suşu ile enfekte olurken, fetüsün yeterli bir bağışıklık yanıtı yoktur. Bu nedenle fetüste persistent enfeksiyon gelişir ve virüs buzağı yaşadığı müddette vücudunda kalır. Persistent enfekte olmuş hayvanlar viremiktir (virüs-pozitif ve antikor-negatif veya seronegatif). Bu hayvanlar tüm vücut salgılarıyla sürekli olarak büyük miktarda virüs saçarlar; virüsün sürüde kalmasını sağlarlar. Sığır popülasyonlarında bir virüs rezervuarıdır (Zimmer ve ark. 2004). Sığır popülasyonlarında ortaya çıkan bozukluklar ve virüsün persistent karakteri sığır endüstrisinde önemli ekonomik kayıplara neden olmaktadır. Enfeksiyon, sürdürülebilir sığır yetiştiriciliği için bir tehdit unsuru olarak kabul edilir (Gunn ve ark. 2005; Houe ve ark. 2006).

Bingöl ilinin fiziksel, coğrafi konumu tarımsal faaliyetleri büyük ölçüde belirler niteliktedir. Şehrin yaklaşık \% 42'sini oluşturan geniş mera alanlarının varlığı (Kaynak: Bingöl III Tarım ve Orman Müdürlüğü, 2016) tarımsal faaliyet içerisinde hayvancılığı birinci plana taşımaktadır. Bingöl büyükbaş hayvan sayısı bakımından 125 bin civarında hayvan varlığı (Kaynak: Bingöl İl Tarım ve Orman Müdürlüğü,2016) ile sığır yetiştiriciliğinin yapıldığı önemli merkezlerden biridir (Esen 2017). BVDV dünya çapında seroprevalansının \% 40-80 arasında, persistenliğinin \% 0,5 ile 4 olduğu endemik bir hastalıktır (Vargas ve ark. 2009). Sürüde PI hayvanlarının belirlenmesi ve uzaklaştırılması kontrol ve eradikasyon programlarının temel özelliğini oluşturur. Bununla birlikte iyi bir sürü yönetimi ve aşılamaların düzenli ve zamanında yapılması da çok önemlidir (Duncan ve ark. 2016; Alpay ve ark. 2019).

Hastalıkla yapılacak mücadele stratejilerini ortaya koymak için PI hayvanların dağılım ve durumunu belirlemek gerekmektedir. Bu nedenle, çalışmanın amacı, BVDV'nin Bingöl'deki varlığını ve yaygınlığını belirlemek ve persistentliğinin oranını ortaya koymaktır.

\section{Gereç ve Yöntem}

Kan numuneleri Bingöl il merkezinde yetiştirilen sığırlardan rastgele örnekleme metodu ile yapılmıştır. Bingöl Üniversitesi Veteriner Fakültesi kliniklerine değişik amaçlarla getirilen 105 sığırdan sağlanan örnekler, Bingöl Üniversitesi Hayvan Deneyleri Yerel Etik Kurulundan alınan onay ve Bingöl II Tarım ve Ormancılık Müdürlüğü'nden alınan izinlere uygun olarak gerçekleştirilmiştir. 2018 yılında yapılan örnekleme çalışmaları 0-59 gün ile 60 gün-10 yaş aralığındaki hayvanlardan 2 grup halinde oluşturulmuştur (Tablo 1).

BVDV antijen tespitinde, tam kan örneği için EDTA'lı steril tüpler kullanılmıştır. İlk testte pozitif olan hayvanlar en az üç hafta sonra barınaklarda tekrar muayene edilmiş ve persistentlik durumunu belirlemek için yeniden kan alınmıştır. Tüm kan örnekleri test edilene kadar $-20^{\circ} \mathrm{C}^{\prime}$ de saklanmıştır.

BVDV antikor tespitinde de vakumlu steril kan toplama tüpleri kullanılmıştır. Her hayvanın vena jugularisinden kan örneği alındıktan sonra serum elde etmek için 3000 devirde 10 dakika boyunca santrifüj edilmiştir. Daha sonra serum numuneleri $56{ }^{\circ} \mathrm{C}$ su banyosunda 30 dakika süreyle inaktive edilmiştir.

\section{ELISA testi ile BVDV Antijeni tespiti}

Tam kan örneklerinde lökosit düzeylerini belirlemek için 3000 rpm'de 10 dakika santrifüj edilmiştir. BVDV antijenleri yönünden tam kan numunelerdeki lökosit tabakası, IDEXX BVDV Ag / Serum Plus Test kiti ile (IDEXX, İsviçre) belirlenmiştir. Test protokolü üretici tarafından önerildiği gibi gerçekleştirilmiş ve test 
sonuçları da ELISA okuyucusunda (Thermo-Multiskan EX, Finlandiya) $450 \mathrm{~nm}$ dalga boyunda değerlendirilmiştir.

\section{ELISA testi ile BVDV Antikoru tespiti}

Kan serumu örneklerinde, BVDV antikor varlığının belirlenmesi için IDEXX BVDV p80 Ab Test kiti (IDEXX, İsviçre) kullanılmıştır. Test protokolü de üretici tarafından önerildiği şekliyle gerçekleştirilmiş ve test sonuçları da ELISA okuyucusunda (Thermo-Multiksan EX, Finlandiya) $450 \mathrm{~nm}$ dalga boyunda değerlendirilmiştir.

\section{İstatistiksel analiz}

Bu çalışmada yaş grupları arasında istatistiksel analiz Chi-Square $\left(X^{2}\right)$ testi (Minitab 16 istatistik yazılımı, $A B D$ ) ve korelasyon testi (Minitab 16 istatistik yazilı$\mathrm{mı}, \mathrm{ABD}$ ) kullanılarak yapılmıştır. $\mathrm{p}<0.05$ istatistiksel olarak anlamlı kabul edildi.

\section{Bulgular}

Bingöl'deki sığır işletmelerinden yaptığımız örneklemede 0-59 gün yaş aralığında bulunan birinci grupta 44 Simental bir tane de Brown Swiss ırkı hayvan yer almıştır. Bu grupta yapılan BVDV virüs testinde 4 örnekte antijen ve 15'inde de antikor bulunmuştur. 60 gün-10 yaş aralığındaki ikinci grupta bulunan toplam 60 hayvanın 57'si Simental, 2'si Brown Swiss ve 1'i de Melez sığır ırkından meydana gelmiştir. BVDV virüs test sonuçlarına göre, 8 'inde antijen ve 25 'inde de antikor saptanmıştır. Bu sonuçlara göre, Bingöl'de yetiştirilen 105 sığırın 12 'sinde (\% 11.42) BVDV antijeni, 40 'ında (\% 38.09) da BVDV antikoru tespit edilmiştir. 0-59 gün yaş gurubundaki 2 sığır ve 60 gün- 10 yaş gurubundaki 1 hayvanda antikor tespit edilemediği halde antijenin var olduğu tespit edilmiştir. Bu hayvanlar bulundukları işletmeler iki ay takibe alındıktan sonra bu hayvanların testleri tekrarlanmıştır. Tekrar yapılan test sonuçlarına göre ilk belirlenen test sonuçlarını koruduğu görülmüştür. Tüm elde edilen sonuçlara göre toplam 105 hayvan içinde 3'ünün (\%2.85) persiste olduğu görülmüştür.

Tablo 1: Örnekleme yapılan hayvanların yaş grupları, cinsiyet, ırk sayıları ve antijen - antikor verileri.

\begin{tabular}{lccccccccccc}
\hline & $\mathbf{n}$ & Hayvanların Yaşı & Dişi & Erkek & Simental & $\begin{array}{c}\text { Brown } \\
\text { Swiss }\end{array}$ & Melez & \multicolumn{2}{c}{ Antijen } & \multicolumn{2}{c}{ Antikor } \\
\hline 1. Grup & 45 & 0-59 gün & 11 & 34 & 44 & 1 & 0 & 4 & 41 & 15 & 30 \\
2. Grup & 60 & 60 gün - 10 yaş & 39 & 21 & 57 & 2 & 1 & 8 & 52 & 25 & 35 \\
\hline
\end{tabular}

Tablo 2: Antijen ve antikor verilerinin yaş gruplarına göre istatistiksel analizleri.

Antijen

\begin{tabular}{ccccccc}
\hline Yaş & $\mathbf{n}$ & Antijen (+) & \% & Antikor (-) & \% & istatistik \\
\hline 0-59 gün & 45 & 4 & 8.9 & 41 & 91.1 & $\mathrm{X}^{2}=0.502$ \\
$\geq 60$ gün & 60 & 8 & 13.3 & 52 & 86.7 & $\mathrm{P}=0.690$ \\
\hline Antikor & & & & & & \\
\hline Yaş & $\mathbf{n}$ & Antijen (+) & $\%$ & Antikor (-) & \% & Istatistik \\
\hline 0-59 gün & 45 & 15 & 33.3 & 30 & 66.7 & $X^{2}=0.757$ \\
$\geq 60$ gün & 60 & 25 & 41.7 & 35 & 58.3 & $P=0.505$ \\
\hline
\end{tabular}

Tabloda görüldüğü gibi yaş grupları arasında istatistiksel anlamlılık saptanmıştır $(p<0.05)$. Ayrıca yaş, seropozitiflik ve seronegatiflik arasındaki korelasyon testine göre seronegatiflik yaşla birlikte artmıştır (Tablo2).

\section{Tartışma ve Sonuç}

BVDV sığırlarda abort, ölü doğum, fötal rezorpsiyon, konjenital malformasyonlar, fetal enfeksiyon, büyüme geriliği, gebelik oranında azalma, konjenital defekt, gelişmemiş buzağı doğumu ve pnömo-enterite neden olmaktadır. Özellikle immunosupresyona yol açması sebebiyle diğer hastalıklar için de hazırlayıCl faktör konumundadır (Walz ve ark. 2010). BVDV, sığırlarda hayvan sağlığına en fazla etkisi olan 10 enfeksiyondan biridir (Edgar 2004). Dünyanın birçok ülkesinde yapılan serolojik ve virolojik çalışmalar hastalığın yüksek oranda sığır popülasyonunda hastalığa neden olduüunu göstermektedir (Erol ve ark.2014). Güney Şili'nin dört büyük bölgesinden toplanan 948 sığır örneğinde BVDV seroprevalanslarını belirlemek için yapılan serum nötralizasyon testinde; sürüdeki 700 ineğin $\geq 1: 5$ titrede $\% 73.8$ 
nin seropozitif olduğu, boğalarda ise seropozitifliğin \% 81.0 olduğunu bildirmiştir (Reinhardt ve ark. 1990). Polonya'da suni tohumlama boğalarından alınan kan numunelerinde boğaların \% 86'sının nötralizan antikorlara sahip olduğu bildirmişlerdir. Ayrıca, analiz edilen kan örneklerinin \% 0.9'unda persiste enfeksiyon (PI) saptanmıştır (Polak ve ark. 1999). Litvanya'da sığır sürülerinde BVDV enfeksiyonunun sığır popülasyonundaki variyasyonları belirlenmiştir. BVDV ile yıllık enfeksiyon riskinin hayvanlarda yaşın büyümesi ile azaldığı ve cinsiyetin de BVDV prevalansı üzerinde hiçbir etkisinin olmadığı belirlenmiştir (Mockeliuniene ve ark. 2004). Türkiye'de 1964 yllında Öncul ve ark. (1964); BVDV enfeksiyonunun ilk tespitini rapor etmişler. Ak ve ark.(2002) Trakya bölgesindeki sığırlarda enfeksiyonun prevalansını \% 13,46, pesistantlığını \% 25 saptamıştır. Burgu ve ark. (2003);Türkiyenin farklı bölgelerinde bulunan 26 süt sığırı işletmesinin tamanında enfeksiyonun varlığını tespit etmiş ve Işletmelerdeki persiste enfeksiyon oranı ise \%0.6 -0.83 olarak hesaplamıştır. Tan ve ark. (2006); Aydın ili çevresinde seropozitifliği \%86, persistentliği \%4.9 olarak saptamıştır. Erol ve ark. (2014); Afyonkarahisar, Burdur ve Denizli illerindeki küçük özel işletmelerden kan serum örneklerinde yaptıkları çalışmalarda sırasıyla \% 84.6, \% 35.7 ve \% 42.8 seropozitiflik tespit etmişlerdir. Gürçay ve ark.(2013); Bingöl ilinde atık yapmış sığır fötüslerinin \% 29.26'sında BVDV antijenini saptamıştır. Çalışmamızda Bingöl ve çevresinde halk elinde bulunan küçük işletmeleden sağlanan numunelerden yapıla çalışmada BVDV antijeni \% 11.42, BVDV antikoru \% 38.09 ve persiste enfeksiyon varlığı da \% 2.85 oranında tespit edilmiştir. Cinsiyetin enfeksiyon oranını üzerine etkisi görülmemiştir. Yaşla seropozitiflik ve seronegatiflik değerler aralarındaki korelasyon testi uygulanmış, buna göre seronegatiflik yaşın artması ile birlikte artmıştır. Dünyada ve Türkiye'de daha önce yapılan çalışmalarla karşılaştırıldığında prevalans ve persistantlık oranlarında uyum görülmektedir.

BVDV dünyada birçok sığır popülasyonda endemik bir hastalık olarak görülmektedir. Enfeksiyonun doğası nedeniyle, enfekte bir hayvanı tamamaen tedavi etme imkânı yoktur. Evcil ya da yabani popülasyondaki PI hayvanlar virüsün önemli rezervuarı, yaşamları boyunca saçıcısı ve sürülerde yayıcısıdır. Birçok ülkede uygulanan tüm kontrol programları, büyük ölçüde $\mathrm{PI}$ hayvanlarının sürülere girmesini önleme, bir şekilde sürüye girmişse saptanması ve çıkarılması esasına dayanır. Sürü içi uygulamlarda PI hayvanlarının erken dönemde, özellikle de do- ğumdan hemen sonra saptanması, BVDV'nin kontrol başarısı için önemlidir. Persiste enfeksiyonlarda, yaşamları boyunca saldıkları büyük miktarda viral partiküller nedeniyle enfekte hayvanların belirlenmesi, viral yayılmanın önlenmesi için iyi bir stratejidir (Greiser-Wilke ve ark 2003;Vargas ve ark 2009; Walz ve ark 2010). Bu araştırmada belirlenen persiste hayvanlar 20 günlük, 59 günlük ve 8 aylık yaşlarda görülmüştür. Ayrıca daha yaşlı hayvanlarda persistantlık durumu bulunmadığı tespit edilmiştir. Bu bulgulara göre persiste hayvanların hayata tutunma olasılıklarının daha düşük olduğu sonucu çıkarılabilir. Seropozitiflik oranları 6 aylık ve daha büyük hayvanlarda daha yüksek oranda bulunmuştur. Mockeliuniene ve ark. (2004); çalışmalarında seropozitiflik yüzdesinin yaşla birlikte arttığı bildirilmiştir. Ayrıca yaşla birlikte seropozitifliğin artması, sürüde persiste hayvanların varlığına işaret edebilir. Bingöl ve çevresindeki BVDV enfeksiyonunun seropozitifliği ve PI oranı değerlendirildiğinde enfeksiyonun yaygın olduğu değerlendirilebilir.

Sonuç olarak, hastalığa karşı gerekli kontrol ve koruma önlemlerini almak bölge ve ülke ekonomisi adına gereklidir. Biyolojik güvenlik tedbirlerine ek olarak, PI hayvanların bulunması ve eradikasyonu hastalığın kontrolü için fazlasıyla önemlidir (Greiser-Wilke ve ark.2003; Walz ve ark.2010). BVDV enfeksiyonuna karşı aşılamayla bağışıklığı arttırmak en akılcı yöntemlerden biridir. Ancak, piyasada çeşitli inaktif BVDV aşıları bulunmasına rağmen, yetiştiriciler tarafından yeterli düzeyde uygulanmadığı alınan anamnez bilgilerinden anlaşılmıştır. Tüm bu bilgilerin ışığında, yapılan araştırma gerek yetiştiricilere, gerekse alanda çalışan veteriner hekimlere hastalığın yaygınlığını göstermiş, özellikle enfekte/persiste enfekte olan hayvanların eradikasyon çalışmalarına ışık tutacağı, dolaylı olarak ekonomiye destek sağlayacağı düşünülmüştür.

\section{Deney hayvanları kullanımı etik kurulu ve diğer} etik kurul kararları ve izinler: Bingöl Üniversitesi Hayvan Deneyleri Yerel Etik Kurulunun 09/01/2018509 tarih sayısı ve Tarım ve Orman Bakanlığı, Gıda Kontrol Genel Müdürlüğünün 21.12.2017 tarih ve E.3276561 sayılı yazıları ile proje bazlı izinleri alınmıştır.

Maddi destek ve çıkar ilişkisi: Bu çalışma Bingöl Üniversitesi Bilimsel Araştırma Projeleri (BAP) Birimi tarafından, BAP- VF. 2018.00.001 proje numarası ile desteklenmiştir, yazarların herhangi bir çıkara dayalı ilişkisi yoktur. 


\section{Kaynaklar}

1. Ak S, Fırat I, Bozkurt HH, Gülyaz V, Ak K. (2002). The prevalence of bovine viral diarrhoea virus (BVDV) infections in cattle and existence of persistently infected cattle in the Trakya Region. Turk J Vet Anim Sci. 26, 245-248.

2. Alpay G, Toker EB, Yeşilbağ K. (2019). Persistent BVD virüs infections in offspring from imported heifers. Trop Animal Health Prod. 51, 297-302.

3. Burgu İ, Alkan F, Özkul A, Yeşilbağ K, Karaoğlu T, Güngör B. (2003). Türkiye'de süt sığırcılığı işletmelerinde bovine viral diarrhea (BVDV) enfeksiyonunun epidemiyolojisi ve kontrolü. Ankara ÜnivVet Fak Derg. 50, 127-133.

4. Donis RO, (1995). Molecularbiology of bovine viral diarrhea virüs and its interactions with the host. In: Ž. Baker JC, Houe H. Eds. , Bovine Viral DiarrheaVirus. Vet. Clin. North Am.: Food Anim. Pract. 11 pp. 393-424.

5. Duncan AJ, Gunn GJ, Humphry RW. (2016). Difficulties arising from the variety of testing schemesused for bovine viral diarrhoea virus (BVDV). Vet Record. 178, 292-292.

6. Edgar RC, (2004). MUSCLE: multiple sequence alignment with high accuracy and high through put. Nucleic Acids Res. 32, 1792-1797.

7. Erol N, Gür S, Acar A. (2014). A Serological investigation for Bovine Viral Diarrhea Virus infection in and around Afyonkarahisar province West Anatolia. Kocatepe Vet J. 7, 17-21.

8. Esen F, (2017) "Bingöl İli'nde Büyükbaş ve Küçükbaş Hayvancılık Faaliyetleri". Bingöl Üni. Sos. Bil. Enst. Derg. 7, 13, 83-100.

9. Fray MD, Paton D J, Alenius S. (2000).Thee ffects of bovine viral diarrhoea virus on cattle reproduction in relation to disease control. Anim Reprod Sci. 60, 615-627.

10. Greiser-Wilke I, Grummer B, Moennig V. (2003). Bovine viral diarrhoea eradication and control programmes in Europe. Biologicals. 31,113-118.

11. Gunn GJ, Saatkamp HW, Humphry RW, Stott AW. (2005) Asessing economic and social pressure for the control of bovine viral diarrhoea virus. PrevVet Med, 72,149-162.

12. Gürçay M, İssi M, Gül Y. (2013). Investigation of bovine viraldiarrhoea virus in dairy cattle premises where aborts occur. Erciyes Üniv Vet Fak Derg, 10,2, 101-105.

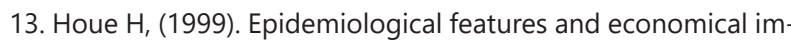
portance of bovine virüs diarrhoea virüs (BVDV) infections. Vet Microbiol. 64, 89- 107.

14. Houe H, Lindberg A, Moennig V. (2006). Test strategies in bovine viral diarrhea virus control and eradication campaigns in Europe. J Vet Diagn Invest, 18, 427-436.

15. Mockeliuniene V, Salomskas A, Mockeliunas R, Petkevicius $S$. (2004). Prevalence and epidemiological features of bovine viral diarrhoea virüs infection in Lithuania. Vet. Microbiol, 99, 51-57.

16. Oğuzoğlu TÇ, Koç B T, Coşkun N, Doğan F, Duran-Yelken S. (2019). Endless variety for bovine virüs diarrhea viruses: newmembers of a novel subgroup in to Pestivirus A from Turkey. Trop Animal Health Prod, 51, 1083-1087.

17. Öncül S, Meriç İ, Korkut F. (1964). Türkiye'de ilk defa Lalahan Zootekni Araştırma Enstitüsü Sığırlarında tespit edilen $\mathrm{Mu}$ cosal Disease'in klinik yönü. Lalahan Zoo Arş Enst Derg. 4 186-189.

18. Polak MP, Zmudsinki JF. (1999). Prevalance of bovine viral diarrhea virüs infection in bulls in artificial insemination centers in Poland. Vet Microbiol, 64, 253-257.

19. Reinhardt G, Riedmann S, Ernst S, Aguilar M, Enriquez R, Gallardo J. (1990). Seroprevalance of Bovine Viral Diarrhea / Mucosal Disease in Southern Chile. PrevVetMed, 10, 73-78.

20. Richter V, Lebl K, Baumgartner W, Obritzhauser W, Käsbohrer A, Pinior B. (2017). A systematic worldwide review of the direct monetary losses in cattle due to bovine viral diarrhoea virüs infection. Vet J, 220, 80-87.

21. Tan MT, Karaoğlu T, Erol N, Yıldırım Y. (2006). Serological and virological investigations of bovine viral diarrhoea virus (BVDV) infection in dairy cattle herds in Aydın province. Turk $J$ Vet Anim Sc, 30, 299-304.

22. Vargas D, Jaime J, Vera V. (2009). Perspectivas para el contro del Virus de la Diarrea Viral Bovina (BVDV). Rev Colomb Cienc Pecu, 22,677-88.

23. Walz PH, Grooms DL, Passler T, Ridpath JF, Tremblay R, Step DL, Callan RJ, Givens MD. (2010). Control of Bovine Viral Diarrhea Virus in Ruminants. J Vet Intern Med, 24, 476-486.

24. Zimmer GM, Van Maanen C, De Goey I, Brinkhof J, Wentink $\mathrm{GH}$. (2004). The effect of maternal antibodies on the detection of bovine virüs diarrhoea virus in peripheral blood samples. Vet. Microbiol, 100, 145-149. 